\title{
KEMAMPUAN PESERTA DIDIK KELAS VIII SMP NEGERI 1 TELAGA MENGIDENTIFIKASI UNSUR-UNSUR DRAMA DALAM PEMBELAJARAN BAHASA INDONESIA
}

\author{
Sri Gitawati Umar' ${ }^{1}$ Fatmah AR. Umar ${ }^{2}$, Herman Didipu ${ }^{3}$ \\ Prodi Pendidikan Bahasa dan Sastra Indonesia \\ Fakultas Sastra dan Budaya Indonesia, Universitas Negeri Gorontalo \\ *corresponding srigitawatiumar98@gmail.com \\ Universitas Negeri Gorontalo,faruung@gmail.com \\ Universitas Negeri Gorontalo, herdi.ung@gmail.com
}

\begin{abstract}
Abstrak
Penelitian ini bertujuan (1) mendeskripsikan kemampuan peserta didik kelas VIII SMP Negeri 1 Telaga mengidentifikasi unsur-unsur drama dalam pembelajaran bahasa Indonesia. Metode yang digunakan dalam penelitian ini adalah metode deskriptif. Teknik pengumpulan data menggunakan teknik tes kemampuan dan kuensioner (angket). Data yang diperoleh dalam penelitian ini adalah kemampuan peserta didik mengidentifikasi unsur drama, ratarata 67 dengan kategori kurang, Hal ini dibuktikan dari kemampuan mengidentifikasi tema rata-rata 70 dikategorikan kurang, kemampuan mengidentifikasi alur drama rata-rata 71 dikategorikan kurang, kemampuan mengidentifikasi penokohan rata-rata 68 dikategorikan kurang, kemampuan mengidentifikasi latar rata-rata 72 dikategorikan cukup, kemampuan mengidetifikasi dialog rata-rata 58 dikategorikan sangat kurang, kemampuan mengidentifikasi amanat rata-rata 60 dikategorikan sangat kurang.Secara keseluruhan kemampuan peserta didik mengidentifikasi unsur-unsur drama rata-rata 67 dikategorikan kurang. (2) Faktor-faktor penghambat peserta didik mengidentifikasi unsur-unsur drama dikategorikan cukup dipengaruhi oleh faktor peserta didik, faktor sekolah, faktor sarana dan prasarana. (3) Solusi terhadap faktor penghambat peserta didik mengidentifikasi unsur-unsur drama disesuaikan dengan karakteristik peserta didik, karakteristik sekolah, karakteristik sarana dan prasarana. Jadi dapat disimpulkan kemampuan peserta didik mengidentifikasi unsur-unsur drama dalam kategori kurang.
\end{abstract}

Kata-kata Kunci: Kemampuan, Mengidentifikasi, Unsur-unsur Drama.

Abstract

This study aims to describe the ability of eighth-gradersin SMP 1 state junior high school of telaga in identifying the elements of drama in Indonesia Language Subject, the factors that inhibit the ability, and solutions to the inhibitors. This descriptive research collectsthe data using ability tests and questionnaires to measure the students' ability in identifying the elements of drama, obtaining an average of 67 categorized as "less", It is evidenced from the ability to identify the theme with an average of 70 categorized as "less", the ability to identify the drama plot with an average of 71 categorized as "less", the ability to identify characterizations with an average of 68 categorized as "less", the ability to identify the background with an average of 72 categorized as "adequate", the ability to identify the dialog 
with an average of 58 categorized as "poor", the ability to identify the moralwith an average of 60 categorized as "poor". Furthermore, the inhibitorsof the abilities identified factors of students, school, facilities, and infrastructure influence, and the solutions to theseinhibitionsare to adapt to the characteristics of said factors. This research is concluded with thestudents' ability to identify the elements of drama in the "less" category.

Keywords: Ability, Identifying, Elements of Drama.

\section{PENDAHULUAN}

Drama merupakan karya sastra yang mengungkapkan cerita melalui dialog-dialog para tokohnya. Menurut Sumaryanto (2019:1) Drama adalah bentuk karya sastra yang bertujuan menggambarkan kehidupan dengan menyampaikan pertikaian dan emosi melalui lakuan dan dialog. Lakuan dan dialog dalam drama tidak jauh berbeda dengan lakuan serta dialog yang terjadi dalam kehidupan sehari-hari. Drama dapat dipandang sebagai seni sastra dan seni tersendiri, yaitu seni drama. Drama sebagai seni sastra dapat terlihat dari naskah drama yang ditulis oleh pengarang. Menurut Syukron, (2016:50) Drama adalah karya sastra yang bertujuan menggambarkan kehidupan dengan menyampaikan pertikaian dan emosi dengan gerak dan dialog yang dipentaskan. Drama bukan hanya dibaca, tetapi juga untuk dipentaskan.

Menurut (Waluyo 2002:2) ada dua kemungkinan jika berbicara tentang drama, yaitu drama naskah dan drama pentas. Drama naskah adalah teks yang berisikan dialog dengan gambaran karakter-karakter tokoh didalamnya, berfungsi sebagai naskah drama yang dibaca. Sedangkan Drama pentas adalah drama yang beritegrasi dengan berbagai jenis kesenian seperti musik, tata lampu, seni kostum, dan lain sebagainya. Menurut waluyo (2002:8) unsurunsur drama meliputi plot atau kerangka cerita, penokohan dan perwatakan, dialog, tema/nada dasar cerita, setting/landasan/tempat kejadian, amanat.

Plot merupakan jalinan cerita atau kerangka dari awal hingga akhir yang merupakan jalinan konflik antara dua tokoh yang berlawanan. Konflik itu berkembang karena kontradiksi para pelaku. Sifat dua tokoh utama itu bertentangan misalnnya, kebaikan kontra kejahatan, tokoh sopan kontra tokoh brutal, tokoh pembela kebenaran kontra bandit, tokoh ksatria kontra penjahat, tokoh bermoral kontra tokoh tidak bermoral, dan sebagainya. Konflik itu semakin lama semakin meningkat untuk kemudian mencapai titik klimaks (kejadian). Setelah klimaks lakon akan menuju penyelesaian. Seperti halnya alur atau plot dalam prosa fiksi, plot dramapun dapat dipilah ke dalam tiga bagian besar cerita, yaitu bagian awal, tengah, dan akhir. Bagian awal cerita biasanya berisi paparan awal tentang latar cerita dan perkenalan tokoh-tokoh cerita. Bagian tengah cerita biasanya berisi konflik atau klimaks. Sementara bagian akhri biasanya berisi penyelesaian cerita.

Penokohan erat hubungannya dengan perwatakan. Susunan tokoh (drama pesona) adalah daftar tokoh-tokoh yang berperan dalam drama itu. Dalam susunan tokoh itu, yang terlebih dulu dijelaskan adalah nama, umur, jenis kelamin, tipe fisik, jabatan, dan keadaan kejiwaannya itu. Penulis lakon sudah menggambarkan perwatakan tokoh-tokohnya. Watak tokoh itu akan terjadi nyata terbaca dalam dialog dan catatan samping. Jenis dan warna dialog akan menggambarkan watak tokoh itu. Dalam wayang kulit atau wayang orang, tokohtokohnya sudah memiliki watak yang khas, yang didukung pula dengan gerak-gerik, suara, panjang pendeknya dialog, jenis kalimat dan ungkapan yang digunakan. Tokoh-tokoh dalam 
drama dapat diklasifikasi menjadi beberapa, seperti berikut ini (1) Tokoh protagonis, yaitu tokoh yang mendukung cerita. Biasanya ada satu atau dua figure tokoh protagonis utama, yang dibantu oleh tokoh-tokoh lainnya yang ikut terlibat sebagai pendukung cerita, (2) Tokoh antagonis, yaitu tokoh penentang cerita. Biasanya ada seorang tokoh utama yang menentang cerita, dan beberapa figur pembantu yang ikut menentang cerita, (3) Tokoh Tritagonis, yaitu tokoh pembantu, baik untuk tokoh protagonis maupun untuk tokoh antagonis.

Dialog adalah ciri khas suatu drama yang berbentuk naskah cakapan atau dialog. Dalam menyusun dialog ini pengarang harus benar-benar memperhatikan pembicaraan yang ditulis oleh pengarang naskah drama adalah pembicaraan yang akan diucapkan dan harus pantas untuk diucapkan di atas panggung. Menurut Kosasih (2017:206), dalam dialog itu sendiri, ada tiga elemen yang tidak boleh dilupakan ketiga elemen tersebut adalah tokoh, wawancang dan kramagung. (1) Tokoh adalah pelaku yang mempunyai peran yang lebih dibandingkan pelaku-pelaku lain, sifatnya bisa protagonis atau antagonis, (2) Wawancang adalah dialog atau percakapan yang harus diucapkan oleh cerita, (3) Kramagung adalah petunjuk perilaku, tindakan, atau perbuatan yang harus dilakukan tokoh. Dalam naskah drama, karamgung dituliskan dalam tanda kurung (biasanya dicetak miring).

Pratiwi \& Frida Siswiyanti (2014:86-90) menemukakan bahwa setting (latar) dalam naskah drama diwujudkan dalam tiga bentuk yaitu (1) Setting tempat, merupakan latar tempat sering disebut sebagai latar fisik karena memiliki wujud dan dapat dilihat, (2) Setting waktu, merupakan latar penceritaan dalam naskah drama yang menunjukkan keterangan waktu (kapan peristiwa dalam cerita terjadi). Misalnya, satuan waktu berdasarkan perubahan suasana malam hari, siang hari, pagi hari, musim hujan, musim kemarau, (3) Setting suasana, berhubungan dengan suasana yang dibagun dalam cerita. Setting suasana berhubungan dengan kondisi psikologis tokoh, ditandai dengan lahirnya suasana yang dapat mengikat perasaan tokoh dan pembaca sehingga mampu ikut merasakan suasana yang dibagun dalam cerita.

Waluyo (2002:24) mengemukakan bahwa tema merupakan gagasan pokok yang terkandung dalam drama. Tema berhubungan dengan premis dari drama tersebut yang berhubungan pula dengan nada dasar dari sebuah drama dan sudut pandang yang dikemukakan oleh pengarangnya. Amanat yang hendak disampaikan pengarang melalui dramanya harus dicari oleh pembaca atau penonton. Seorang pengarang drama pasti menyampaikan amanat dalam karyanya itu. Pembaca yang cukup teliti akan dapat menangkap apa yang tersirat di balik yang tersurat. Amanat yang hendak disampaikan oleh pengarang perlu diberikan beberapa altarnatif. Dalam menafsirkan amanat itu, kita dapat bersifat akomodatif. Amanat sebuah drama akan lebih mudah dihayati penikmat, jika drama itu dipentaskan. Amanat itu biasanya memberikan manfaat dalam kehidupan secara praktis (Waluyo, 2002:28).

\section{METODE}

Metode yang digunakan dalam penelitian ini adalah metode deskriptif. Sukmadinata berpendapat (2009:72) bahwa penelitian deskriptif adalah suatu bentuk mendeskripsikan atau menggambarkan fenomena-fenomena yang ada, baik fenomena yang bersifat ilmiah ataupun rekayasa manusia. Jenis penelitian yang digunakan dalam penelitian ini adalah deskriptif kualitatif. Jenis penelitian tersebut dipilih untuk mengetahui kemampuan peserta didik dalam mengidentifikasi unsur-unsur drama, faktor-faktor penghambat peserta didik, serta solusi 
terhadap faktor penghambat peserta didik di kelas VIII4 SMP Negeri 1 Telaga mengidentifikasi unsur-unsur drama.

Teknik pengumpulan data dalam penelitian ini menggunakan dua teknik yaitu data tes kemampuan dan angket. Tes kemampuan adalah suatu cara untuk melakukan penilaian yang berbentuk tugas-tugas yang harus dikerjakan peserta didik. Angket merupakan teknik pengumpulan data yang dilakukan dengan cara memberi seperangkat pertanyaan atau pernyataan tertulis kepada responden untuk dijawabnya. Angket ini ditunjukan kepada peserta didik kelas VIII4 SMP Negeri 1 Telaga. Hal ini dimaksudkan untuk memperoleh informasi, deskripsi tentang faktor-faktor penghambat kemampuan peserta didik kelas VIII4 SMP Negeri 1 Telaga mengidentifikasi unsur-unsur drama dan solusi terhadap faktor penghambat peserta didik kelas VIII4 SMP Negeri 1 Telaga mengidentifikasi unsur-unsur drama.

\section{HASIL PENELITIAN}

Pada bagian ini diuraikan tentang kemampuan peserta didik kelas VIII SMP Negeri 1 Telaga mengidentifikasi unsur-unsur drama, faktor-faktor penghambat kemampuan peserta didik mengidentifikasi unsur-unsur drama, serta solusi terhadap faktor penghambat peserta didik mengidentifikasi unsur-unsur drama. Kemampaun peserta didik mengidentifikasi unsur tema dalam teks drama "Sayang Ada Orang Lain" dari 29 orang peserta didik yang mengidentifikasi tema dengan tingkat penguasaan 100 berjumlah 9 orang, yang memperoleh tingkat penguasaan 80 berjumlah 2 orang, yang memperoleh tingkat penguasaan 60 berjumlah 16 orang, dan yang memperoleh 0 berjumlah 2 orang.

Kemampuan mengidentifikasi alur dalam teks drama, dari 29 orang peserta didik yang mengidentifikasi alur dengan memperoleh tingkat penguasaan 100 berjumlah 7 orang, yang memperoleh tingkat penguasaan 80 berjumlah 4 orang dan yang memperoleh tingkat penguasaan 60 berjumlah 17 orang dan yang memperoleh 0 berjumlah 1 orang.

Kemampuan mengidentifikasi penokohan dalam teks drama, dari 29 oang peserta didik yang mengidentifikasi penokohan dengan memperoleh tingkat penguasaan 100 berjumlah 8 orang, yang memperoleh tingkat penguasaan 80 berjumlah 6 orang, yang memperoleh tingkat penguasaan 60 berjumlah 12 orang dan yang memperoleh skor 0 berjumlah 3 orang.

Kemampuan mengidentifikasi unsur latar dalam teks drama, dari 29 orang peserta didik yang mengidentifikasi latar dengan memperoleh tingkat penguasaan 100 berjumlah 5 orang, yang memperoleh tingkat penguasaan 80 berjumlah 17 orang, yang memperoleh tingkat penguasaan 40 berjumlah 6 orang dan yang memperoleh tingkat penguasaan 0 berjumlah 1 orang. 


\begin{tabular}{|c|c|c|c|c|c|c|c|c|c|c|}
\hline \multirow{2}{*}{ No } & \multirow{2}{*}{ Nama Peserta Didik } & \multicolumn{6}{|c|}{ Tingkat Penguasaan Perunsur } & \multirow[t]{2}{*}{$\begin{array}{l}\mathrm{T} . \\
\mathrm{P}\end{array}$} & \multirow[t]{2}{*}{ Ket } & \multirow[t]{2}{*}{ KKM } \\
\hline & & $\mathrm{T}$ & $\mathrm{AL}$ & $\mathrm{P}$ & $\mathrm{L}$ & $\mathrm{D}$ & $\begin{array}{l}\mathrm{A} \\
\mathrm{M}\end{array}$ & & & \\
\hline 1. & Firawati Hasan & 100 & 100 & 100 & 100 & 80 & 100 & 96 & $\begin{array}{l}\text { Amat } \\
\text { Baik }\end{array}$ & Tuntas \\
\hline 2. & Rafli Kadir & 100 & 100 & 100 & 80 & 80 & 100 & 93 & $\begin{array}{c}\text { Amat } \\
\text { Baik }\end{array}$ & Tuntas \\
\hline 3. & Desriani Hasan & 100 & 100 & 100 & 80 & 100 & 60 & 90 & Baik & Tuntas \\
\hline 4. & Ikbal Frimulya Rahman & 100 & 100 & 100 & 100 & 100 & 40 & 90 & Baik & Tuntas \\
\hline 5. & Zuliqbal Malapo & 100 & 100 & 100 & 100 & 40 & 100 & 90 & Baik & Tuntas \\
\hline 6. & $\begin{array}{l}\text { Mohamad Rafli Akbar } \\
\text { Rasjid }\end{array}$ & 100 & 100 & 100 & 100 & 80 & 60 & 90 & Baik & Tuntas \\
\hline 7. & Amanda Mariani Buloto & 0 & 100 & 80 & 80 & 80 & 60 & 78 & Cukup & Tuntas \\
\hline 8. & Fina Oktavini Hasan & 100 & 100 & 60 & 80 & 40 & 100 & 80 & Cukup & Tuntas \\
\hline 9. & Friska Pou & 100 & 80 & 80 & 80 & 80 & 60 & 80 & Cukup & Tuntas \\
\hline 10. & Natalia Mohamad & 60 & 60 & 80 & 80 & 60 & 100 & 73 & Cukup & Tuntas \\
\hline 11. & $\begin{array}{ll}\text { Suciaty } & \text { Mahmud } \\
\text { Abdulrahman } & \\
\end{array}$ & 100 & 80 & 60 & 80 & 80 & 40 & 73 & Cukup & Tuntas \\
\hline 12. & Mohamad Novaldi Danggi & 60 & 60 & 60 & 80 & 60 & 80 & 66 & Kurang & T. Tuntas \\
\hline 13. & Ariel Ali Latif Sango & 60 & 60 & 80 & 80 & 40 & 60 & 63 & Kurang & T. Tuntas \\
\hline 14 & Mutiara Muhammad Fauzi & 60 & 60 & 60 & 40 & 100 & 60 & 63 & Kurang & T. Tuntas \\
\hline 15. & $\begin{array}{l}\text { Nofriyanti } \quad \text { Suleman } \\
\text { Ahmad }\end{array}$ & 80 & 60 & 100 & 80 & 40 & 40 & 66 & Kurang & T. Tuntas \\
\hline 16. & Riang Cahya Lateka & 60 & 80 & 100 & 100 & 40 & 40 & 70 & Kurang & T. Tuntas \\
\hline 17. & Salwa Srioktavia A. Tumu & 60 & 60 & 80 & 80 & 40 & 60 & 63 & Kurang & T. Tuntas \\
\hline 18 & Mohamad Rizki H. Kimun & 60 & 60 & 80 & 80 & 40 & 60 & 63 & Kurang & T. tuntas \\
\hline 19 & Dita Putriansyah Hamzah & 60 & 60 & 60 & 40 & 80 & 60 & 60 & S. Kurang & T. Tuntas \\
\hline 20 & Farma Thalib & 80 & 60 & 0 & 80 & 40 & 60 & 53 & S. Kurang & T. Tuntas \\
\hline 21. & Marsya Agustina Wagiu & 60 & 60 & 60 & 80 & 80 & 60 & 53 & S. Kurang & T. Tuntas \\
\hline 22. & $\begin{array}{l}\text { Mohamad Adriyanto } \\
\text { Sabihi }\end{array}$ & 60 & 60 & 60 & 80 & 40 & 60 & 60 & S. Kurang & T. Tuntas \\
\hline 23. & Nur Amelia Hasan & 60 & 60 & 60 & 80 & 40 & 60 & 60 & S. Kurang & T. Tuntas \\
\hline 24. & Rahmatia Husain & 60 & 60 & 60 & 40 & 80 & 60 & 60 & S. Kurang & T. Tuntas \\
\hline 25. & Risna Idris & 60 & 60 & 0 & 80 & 40 & 60 & 50 & S. Kurang & T. Tuntas \\
\hline 26. & Sitty Rahmatia Puliki & 60 & 60 & 60 & 40 & 60 & 60 & 56 & S. Kurang & T. Tuntas \\
\hline 27. & Sri Rahmatya Idrak & 60 & 60 & 60 & 40 & 80 & 60 & 60 & S. Kurang & T. Tuntas \\
\hline 28 & Adit Setiwan Nupu & 60 & 60 & 60 & 40 & 80 & 0 & 50 & S. Kurang & T. Tuntas \\
\hline 29 & Adrian Umar & 0 & 0 & 0 & 0 & 0 & 0 & 0 & S. Kurang & T. Tuntas \\
\hline Ting & kat Penguasaan & 70 & 71 & 68 & 72 & 58 & 60 & 67 & Kurang & T. Tuntas \\
\hline $\begin{array}{l}\text { Kem } \\
\text { Keter }\end{array}$ & $\begin{array}{l}\text { mpuan Mengidentifikasi } \\
\text { angan: }\end{array}$ & & & & & & & & & \\
\hline $\mathrm{T}$ & :Tema & & & & & & & & & \\
\hline AL & : Alur & & & & & & & & & \\
\hline$P$ & : Penokohan & & & & & & & & & \\
\hline $\mathrm{L}$ & : Latar & & & & & & & & & \\
\hline
\end{tabular}


Jambura Journal of Linguistics and Literature

Vol. I, No. 2, Hal. 45 - 54, Desember 2020

https://ejurnal.ung.ac.id/index.php/jill

D : Dialog

AM : Amanat

T.P : Tingkat Penguasaan

Kemampuan mengidentifikasi unsur dialog dalam teks drama, dari 29 orang peserta didik yang mengidentifikasi dialog dengan memperoleh tingkat penguasaan 100 berjumlah 3 orang, yang memperoleh tingkat penguasaan 80 berjumlah 11 orang, yang memperoleh tingkat penguasaan 60 berjumlah 3 orang, yang memperoleh tingkat penguasaan 40 berjumlah 11 orang, yang memperoleh tingkat penguasaan 0 berjumlah 1 orang.

Kemampuan mengidentifikasi unsur amanat dalam teks drama, dari 29 orang peserta didik yang mengidentifikasi amanat dengan memperoleh tingkat penguasaan 100 berjumlah 5 orang, yang memperoleh tingkat penguasaan 80 berjumlah 1 orang, yang memperoleh tingkat penguasaan 60 berjumlah 17 orang, yang memperoleh tingkat penguasaan 40 berjumlah 4 orang dan yang memperoleh tingkat penguasaan 0 berjumlah 2 orang.

Kemampuan mengidentifikasi unsur-unsur drama secara keseluruhan rata-rata yang memperoleh kategori amat baik berjumlah 2 orang dengan KKM tuntas, yang memperoleh kategori baik berjumlah 4 orang, yang memperoleh kategori cukup berjumlah 5 orang, yang memperoleh kategori kurang berjumlah 7 orang, yang memperoleh kategori sangat kurang berjumlah 11 orang.

\section{Faktor-faktor yang Menghambat Kemampuan Peserta Didik dalam Mengidentifikasi unsur-unsur Drama}

Hasil kemampuan peserta didik dalam mengidentifikasi unsur-unsur drama rata-rata peserta didik memperoleh nilai 67 dengan kategori kurang. Hal ini terjadi karena terdapat faktor-faktor yang mempengaruhinya baik ditinjau dari faktor peserta didik, faktor sekolah, faktor sarana dan prasarana. Berdasakan hasil jawaban angket yang dibagikan kepada peserta didik, diperoleh informasi sebagai berikut.

\section{Faktor Peserta Didik}

Pembelajaran mengidentifikasi unsur-unsur drama belum maksimal dan efektif dalam pelaksanaanya, dikarenakan masih terdapat faktor-faktor penghambat yang bersumber dari peserta didik, Faktor-faktor penghambat tersebut yakni peserta didik tidak siap belajar daring, sebagian peserta didik bersifat pasif, minat dan motivasi peserta didik menurun. Secara rinci faktor peserta didik diuraikan sebagai berikut.

\section{Peserta Didik tidak Siap Belajar}

Ketidaksiapan peserta didik mengikuti pembelajaran bahasa Indonesia terutama materi mengidentifikasi unsur-unsur drama. Dapat dilihat saat peneliti memulai pembelajaran melalui panggilan video, tetapi hanya sebagian peserta didik yang dapat mengikuti pembelajaran daring disebabkan peserta didik sulit mengikuti pembelajaran daring karena sebagian peserta didik kelas VIII4 tidak memiliki handphone atau telepon pintar.

\section{Sebagian Peserta Didik Bersifat Pasif}

Pada saat peneliti melakukan pembelajaran daring melalui panggilan video dan grup whatsapp beberapa peserta didik kurang berperan aktif. Hanya sebagian peserta didik yang dapat mengikuti pembelajaran dan berani bertanya melalui pembelajaran daring. 


\section{Minat dan Motivasi Peserta Didik}

Berdasarkan jawaban angket peserta didik, diperoleh bahwa peserta didik tidak memiliki minat dan motivasi dalam pembelajaran daring. Peserta didik lebih senang belajar tatap muka dibandingkan harus belajar daring. Pembelajaran yang dilakukan secara daring menyebabkan peserta didik lebih pusing menggunakan aplikasi dan sulit menggerjakan tugas di rumah kerena kurangnya sumber belajar dan tidak fokus saat belajar.

\section{Faktor Sekolah}

Selama adanya virus corona atau covid-19 menyebabkan sekolah ditutup. Proses belajar mengajar dilakukan di rumah masing-masing. Dengan adanya covid-19 yang seharusnya pembelajaran yang dilakukan di dalam kelas dengan tatap muka diubah dengan belajar secara daring atau online. Pembelajaran online ini menyebabkan tidak efektifnya proses pembelajaran. Banyak peserta didik yang tidak bisa ikut pembelajaran karena tidak mempunyai kuota internet dan tidak stabilnya jaringan internet.

\section{Faktor Sarana dan Prasarana}

Beberapa faktor sarana dan prasarana yang menjadi kendala atau penghambat proses belajar mengajar di rumah karena covid-19 yaitu, keterbatasan sumber pembelajaran dan kurangnya penguasaan teknologi baik dari pihak peserta didik dan orang tua.

\section{Solusi terhadap Faktor Penghambat Peserta Didik Kelas VIII SMP Negeri 1 Telaga Mengidentifikasi Unsur-unsur Drama}

Solusi terhadap faktor penghambat peserta didik mengidentifikasi unsur-unsur drama seperti yang dikemukakan di atas, diuraikan sebagai berikut.

\section{Faktor Peserta Didik}

Permasalahan yang terjadi pada peserta didik dapat diatasi dengan meningkatkan kreativitas guru dalam belajar dan penggunaan teknologi, guru harus memberikan motivasi sehingga peserta didik terdorong untuk belajar online.

\section{Faktor Sekolah}

Solusi yang diakibatkan oleh covid-19 yang menyebabkan sekolah ditutup dapat di atasi dengan cara guru harus bisa menguasai metode belajar dari rumah dan media yang beragam untuk menarik minat peserta didik dalam proses pembelajaran online. Guru dapat melakukan pembelajaran bersama di waktu yang sama menggunakan grup media social seperti WhatsApp (WA), telegram, instagram, aplikasi zoom ataupun lainnya sebagai media pembelajaran.

\section{Faktor Sarana dan Prasarana}

Kebutuhan guru dan peserta didik di tengah wabah ini sangat membutuhkan jaringan internet yang stabil tetapi ada juga peserta didik yang belum terjangkau oleh jaringan. Sebaiknya guru tetap melaksanakan kegiatan belajar mengajar dengan menyiapkan modul atau bahan ajar kepada peserta didik yang tidak dapat melakukan pembelajaran online dengan mendatangi setiap rumah peserta didik. Berdasarkan persetujuan dari pihak sekolah dengan 
Jambura Journal of Linguistics and Literature

Vol. I, No. 2, Hal. 45 - 54, Desember 2020

https://ejurnal.ung.ac.id/index.php/ijll

menerapan standar protokol kesehatan coved-19. Mulai dari kesiapan standar perlindungan diri seperti masker, face shield, dan tempat cuci tangan yang layak.

\section{PEMBAHASAN}

Hasil kemampuan peserta didik mengidentifikasi tema rata-rata 70 dikategorikan kurang. Kemampuan peserta didik mengidentifikasi Alur rata-rata 71 dikategorikan kurang. kemampuan peserta didik mengidentifikasi penokohan rata-rata 68 dikategorikan kurang. Kemampuan peserta didik mengidentifikasi latar rata-rata 72 dikategorikan cukup. Kemampuan peserta didik mengidetifikasi dialog rata-rata 58 dikategorikan sangat sangat kurang. Kemampuan peserta didik mengidentifikasi amanat drama rata-rata 60 dikategorikan sangat kurang.

Berdasarkan deskripsi hasil kemampuan peserta didik mengidentifikasi unsur-unsur drama rata-rata 67 dikategorikan kurang. Adapun faktor-faktor yang mempengaruhinya, yakni pertama faktor peserta didik. Faktor-faktor penghambat tersebut yakni peserta didik tidak siap belajar daring, sebagian peserta didik bersifat pasif, minat dan motivasi peserta didik menurun saat belajar daring, hal ini disebabkan karena sebagian peserta didik kelas VIII4 tidak memiliki handphone atau telepon pintar. Kedua faktor sekolah yang ditutup. Selama pendemi covid-19 yang belum berakhir menyebabkan sekolah ditutup, peserta didik harus belajar online. Ketiga, sarana dan prasarana yang menjadi kendala atau penghambat proses belajar mengajar di rumah yaitu keterbatasan sarana pembelajaran dan kurangnya sumber belajar dan penguasaan teknologi baik dari pihak peserta didik dan orang tua.

Faktor-faktor di atas sangat mempengaruhi hasil belajar peserta didik untuk mengatasi hal tersebut, solusinya guru harus memberikan motivasi sehingga peserta didik terdorong untuk belajar online. Guru harus memberikan alokasi waktu yang lebih banyak bagi yang tertinggal karena dengan pembelajaran online ini, lebih banyak peserta didik yang tertinggal di pelajaran. Guru dan peserta didik sangat membutuhkan jaringan internet yang stabil tetapi ada juga peserta didik yang belum terjangkau oleh jaringan dan tidak memiliki android. Sebaiknya guru tetap melaksanakan kegiatan belajar mengajar dengan menyiapkan modul atau bahan ajar kepada peserta didik yang tidak dapat melakukan pembelajaran online. Selaian itu juga alternatif dari sekolah untuk belajar online pihak sekolah memberikan dana kepada guru dan peserta didik untuk mempermudah proses pembelajaran.

\section{SIMPULAN}

Berdasarkan hasil penelitian yang telah dipaparkan dapat disimpulkan sebagai berikut. Kemampuan peserta didik kelas VIII4 mengidentifikasi unsur-unsur drama mendapatkan rata-rata 67 dengan kategori kurang. Faktor-faktor penghambat peserta didik mengidentifikasi unsur-unsur drama dikategorikan cukup dipengaruhi oleh faktor peserta didik, faktor sekolah, faktor sarana dan prasarana. Solusi terhadap faktor penghambat peserta didik mengidentifikasi unsur-unsur drama disesuaikan dengan karakteristik peserta didik, karakteristik sekolah, karakteristik sarana dan prasarana. Jadi dapat disimpulkan bahwa pembelajaran mengidentifikasi unsur-unsur drama di kelas VIII4 di SMP Negeri 1 Telaga dikategorikan kurang. 
Jambura Journal of Linguistics and Literature

Vol. I, No. 2. Hal. 45 - 54, Desember Z020

https://ejurnal.ung.ac.id/index.php/ijll

\section{DAFTAR PUSTAKA}

Kosasih, E. 20017.Bahasa Indonesia. Jakarta: Pusat Kurikulum dan Perbukuan, Balitbang, Komendkbud.

Pratiwi, Yuni \& Frida Siswiyanti. 2014. Teori Drama dan Pembelajarannya. Yogyakarta: Ombak.

Sumaryanto. 2019. Karya Sastra Bentuk Drama. Semarang: Mutiara Angkasa.

Syukron, Ahmad. 2016. Peningkatan Keterampilan Menulis Naskah Drama denagan Metode Picture And Picture. Jurnal Pendidikan Bahasa dan Sastra Indonesia.Volume 5. No 2.

Sukmadinata, Nana Syaodih. 2009. Metode Penelitian Pendidikan. Bandung: PT Remaja Rosdakarya.

Waluyo, Herman J. 2002. Drama Teori dan Pengajarannya.Yogyakarta: PT hanindita Graha Widya. 
Jambura Journal of Linguistics and Literature

Vol. I, No. 2, Hal. 45 - 54, Desember 2020

https://ejurnal.ung.ac.id/index.php/ijll 